\title{
Lamothe-Montravel - Les Trois Pierres
}

\section{(2) OpenEdition \\ Journals}

Édition électronique

URL : http://journals.openedition.org/adlfi/16412

ISSN : 2114-0502

Éditeur

Ministère de la culture

Référence électronique

"Lamothe-Montravel - Les Trois Pierres », ADLFI. Archéologie de la France - Informations [En ligne], Aquitaine, mis en ligne le 10 février 2016, consulté le 30 avril 2019. URL : http://

journals.openedition.org/adlfi/16412

Ce document a été généré automatiquement le 30 avril 2019.

(C) Ministère de la Culture et de la Communication, CNRS 


\section{Lamothe-Montravel - Les Trois Pierres}

Notice non parvenue. 